\title{
Performance Evaluation of Co-Inoculation of Rhizobium, Phosphobacteria and AM Fungi in Greengram var Paiyur1
}

\author{
A. Ramalakshmi* and R. Parimala Devi \\ Regional Research Station, Tamil Nadu Agricultural University, Paiyur-635112, Krishnagiri, \\ Tamil Nadu, India \\ *Corresponding author
}

\section{A B S T R A C T}

\begin{tabular}{|l|}
\hline Ke y w or d s \\
Rhizobium, \\
Phosphobacteria, \\
Greengram
\end{tabular}

A two year field study was conducted at RRS, Paiyur to study the influence of co inoculation of biofertilizers viz., Rhizobium, Phosphobacteria and VAM on soil microflora, plant biometric observation and yield parameters at periodical interval. Treatments consisted of STCR recommended dose of fertilizers along with biofertilizers individually and/ or in combination. The control treatment consisted of STCR recommended dose alone. Results revealed that all the parameters were significantly increased when the treatments containing bioinoculants individually and/or in combination with STCR recommended dose of fertilizer compared with STCR recommended dose alone. The pooled analysis of two year (Kharif 2012 and 2013) data revealed that the co inoculation of Rhizobium, Phosphobacteria and VAM along with STCR recommended dose of fertilizers significantly increased the yield of $1040 \mathrm{~kg} / \mathrm{ha}$ ( 42.5 percent) with cost benefit ratio of 3.35 compared with STCR alone (730kg/ha). The combination of two biofertilizers, Rhizobium along with Phosphobacteria or VAM significantly increased the yield of 22 percent compared with STCR alone.

\section{Introduction}

Pulse crops or grain legumes are the major source of protein in the predominantly vegetarian diet of the people of India. Globally, pulses are the second most important group of crops after cereals. In 2009, the global pulses production was 61.5 million tons from an area of 70.6 million ha with an average yield of $871 \mathrm{~kg} / \mathrm{ha}$. India shares 70 per cent of the total world black gram and green gram production. Green gram is a short duration crop suitable for multiple and relay crop. Though India is the world's largest producer of pulses, it imports a large amount of pulses to meet the growing domestic needs. During 2009-10, India imported 3.5 million tons of pulses from the countries like Australia, Canada, and Myanmar. India has to produce not only enough pulses but also remain competitive to protect the indigenous pulse production (http://oar.icrisat.org/). In view of this, use of biofertilizers as it is one of the important components of integrated nutrient management, as they are cost effective and renewable sources of plant nutrients to supplement the chemical fertilizers for 
sustainable agriculture. The Biofertilizers offer a new technology to Indian agriculture holding a promise to balance many of the shortcomings of the conventional chemical based technology (http://www.ipni.net/).

\section{Materials and Methods}

The experiment was carried out during Kharif 2012 and Kharif 2013 at Regional Research Station, Paiyur as per the technical programme with the following treatments.

The plant biometric observation viz., plant height, number of branches and number of leaves were recorded at different intervals of 30 DAS and 60 DAS. The rhizosphere soil samples were collected during 30DAS and at harvest for enumeration of microorganisms. The number of nodules per plant was recorded during the 30 and 45 DAS. The yield parameters viz., number of pods per plant, pod length, number of seeds per pod, 100 seed weight and seed yield were recorded during harvest. The collected data were subjected to statistical analysis and treatment means were compared with RBD test at 5\% level of significance. As there was no consistent difference between yield components, two components were pooled and subjected to statistical analysis.

\section{Results and Discussion}

\section{Effect of co inoculation of biofertilizers on microbial population}

The phophobacteria and Rhizobium sp were enumerated from the rhizosphere soil samples during 30 DAS and after harvest. The microbial population was increased in all the treatments during 30DAS and subsequently decreased after harvest. The co-inoculation of Rhizobium, Phosphobacteria and VAM showed higher population of Phosphobacteria (40.45 x $\left.10^{6} \mathrm{cfu} / \mathrm{g}\right)$ and Rhizobium $(26.40 \mathrm{x}$ $\left.10^{6} \mathrm{cfu} / \mathrm{g}\right)$ when compared to other treatments (Table 1). Anandraj et al., (2010) reported that combined microbial inoculation on growth nodulation and yield of Green Gram increased the population of total bacteria, Rhizobium sp., Pseudomonas fluorescens and Bacillus megaterium over uninoculated control indicating the ability of the introduced microorganisms to establish themselves in the rhizosphere. The influence of co inoculation of biofertilizers on root nodules was recorded at 30 and 45 DAS. The result showed that the number of nodules was more than doubled from the 30 DAS in almost all the treatments. Maximum number of nodules was observed in the treatment containing combination of Rhizobium, Phosphobacteria, VAM along with STCR recommended dose during 30 and 45 DAS compared to control (Table 2). Javaid et al., (2000) noted a significant increase in nodulation in Vigna radiata due to effective micro-organisms application. In seems probable that soil amendments as well as indigenous population of soil microorganisms determine the nodulation response of host plant to effective micro-organisms application.

The influence of co inoculation of biofertilizers on plant growth parameters viz., plant height and number of leaves per plant were recorded at 30 and 60 DAS and results were presented in Table 3. In general all the growth parameters were increased in the treatment T8 (STCR dose + Rhizobium + Phosphobacteria + AM fungi) at 30 and 60 DAS compared to other treatments. The combination of three biofertilizers (T8) significantly increased the plant height and leaves at 60 DAS followed by combination of two biofertilizers viz., Rhizobium along with phosphobacteria or AM Fungi. The control treatment, STCR recommended dose alone (T1) recorded the lowest plant height of 90.2 $\mathrm{cm}$ at 60DAS. The number of branches were higher in the treatment $\mathrm{T} 8$ (4.53) compared to control T1 (2.93). 
Table.1 Effect of co inoculation of biofertilizers on microbial population in the rhizosphere region of green gram var Paiyur1

\begin{tabular}{|c|c|c|c|c|c|}
\hline \multirow{2}{*}{$\begin{array}{l}\text { Trt. } \\
\text { No. }\end{array}$} & \multirow[t]{2}{*}{ Treatments } & \multicolumn{2}{|c|}{ Phosphobacteria $\left(10^{6} \mathrm{cfu} / \mathrm{g}\right)$} & \multicolumn{2}{|c|}{ Rhizobium $\left(10^{6} \mathrm{cfu} / \mathrm{g}\right)$} \\
\hline & & 30DAS & After harvest & 30DAS & After harvest \\
\hline T1 & STCR recommended dose & 17.55 & 5.00 & 15.3 & 4.90 \\
\hline T2 & $\mathrm{T} 1+$ Rhizobium $(\mathrm{ST}-600 \mathrm{~g} / \mathrm{ha})$ & 21.75 & 7.35 & 23.00 & 6.85 \\
\hline T3 & $\mathrm{T} 1$ + Phosphobacteria (SA-2Kg/ha) & 32.30 & 8.45 & 16.95 & 5.20 \\
\hline $\mathrm{T4}$ & $\mathrm{T} 1+$ AM fungi $\left(\mathrm{SA}-50 \mathrm{~g} / \mathrm{m}^{2}\right)$ & 21.00 & 6.55 & 16.70 & 5.30 \\
\hline T5 & T1+ Rhizobium + Phosphobacteria & 33.45 & 8.30 & 25.05 & 7.55 \\
\hline T6 & $\mathrm{T} 1+$ Rhizobium + AM fungi & 23.20 & 7.10 & 23.85 & 7.60 \\
\hline $\mathrm{T7}$ & T1 + Phosphobacteria + AM fungi & 36.80 & 8.35 & 18.80 & 5.65 \\
\hline T8 & $\begin{array}{l}\text { T1 + Rhizobium }+ \text { Phosphobacteria }+ \\
\text { AM fungi }\end{array}$ & 40.45 & 9.25 & 26.40 & 8.35 \\
\hline
\end{tabular}

Table.2 Effect of co inoculation of biofertilizers on nodules of green gram var Paiyur1

\begin{tabular}{|l|l|r|r|}
\hline $\begin{array}{c}\text { Trt. } \\
\text { No. }\end{array}$ & \multicolumn{1}{|c|}{ Treatments } & \multicolumn{2}{|c|}{ No. of nodules/plant } \\
\hline T1 & STCR recommended dose & 30DAS & 45DAS \\
\hline & $\begin{array}{l}\text { (23kgN+25kgP+12.5kgK+20kgS) } \\
\text { T1 }\end{array}$ & 15.665 & 32.9 \\
\hline T3 & T1 + Phizobium (ST-600g/ha) & 25.815 & 52.965 \\
\hline T4 & T1 + AM fungi (SA-50g/m $\left.{ }^{2}\right)$ & 22.635 & 46.15 \\
\hline T5 & T1+ Rhizobium + Phosphobacteria & 21.35 & 42.585 \\
\hline T6 & T1 + Rhizobium + AM fungi & 26.05 & 59.335 \\
\hline T7 & T1 + Phosphobacteria + AM fungi & 26.435 & 62.335 \\
\hline T8 & T1 + Rhizobium + Phosphobacteria + AM fungi & 23.05 & 50.865 \\
\hline
\end{tabular}

Table.3 Effect of co inoculation of biofertilizers on plant biometric observation in greengram var Paiyur1

\begin{tabular}{|c|c|c|c|c|c|c|}
\hline \multirow{3}{*}{$\begin{array}{l}\text { Trt. } \\
\text { No }\end{array}$} & \multirow[t]{3}{*}{ Treatments } & \multicolumn{5}{|c|}{ DAS } \\
\hline & & \multicolumn{2}{|c|}{$\begin{array}{l}\text { Plant height } \\
\text { (cm) }\end{array}$} & \multicolumn{2}{|c|}{$\begin{array}{l}\text { No. of leaves } \\
\text { /plant }\end{array}$} & \multirow{2}{*}{$\begin{array}{c}\text { No. of branches } \\
\text { /plant } \\
\mathbf{6 0}\end{array}$} \\
\hline & & 30 & 60 & 30 & 60 & \\
\hline T1 & STCR recommended dose & 28.87 & 90.20 & 7.07 & 11.53 & 2.93 \\
\hline $\mathbf{T 2}$ & $\mathrm{T} 1+$ Rhizobium $(\mathrm{ST}-600 \mathrm{~g} / \mathrm{ha})$ & 30.53 & 97.07 & 7.93 & 14.4 & 3.87 \\
\hline T3 & T1 + Phosphobacteria (SA-2Kg/ha) & 28.73 & 95.93 & 7.53 & 12.13 & 3.6 \\
\hline $\mathbf{T 4}$ & $\mathrm{T} 1+\mathrm{AM}$ fungi $\left(\mathrm{SA}-50 \mathrm{~g} / \mathrm{m}^{2}\right)$ & 29.07 & 96.67 & 7.47 & 12.07 & 3.4 \\
\hline T5 & T1+ Rhizobium + Phosphobacteria & 30.2 & 98.80 & 8.13 & 13.6 & 4.07 \\
\hline T6 & $\mathrm{T} 1+$ Rhizobium + AM fungi & 29.73 & 98.40 & 8.2 & 13.87 & 3.8 \\
\hline $\mathbf{T 7}$ & $\mathrm{T} 1+$ Phosphobacteria + AM fungi & 29.0 & 96.53 & 7.27 & 11.73 & 3.53 \\
\hline \multirow[t]{2}{*}{ T8 } & $\mathrm{T} 1+$ Rhizobium + Phosphobacteria + AM fungi & 31.47 & 105.5 & 8.53 & 14.93 & 4.53 \\
\hline & $\mathrm{CD}(0.05 \%)$ & 0.87 & 1.51 & 0.78 & 1.28 & 0.30 \\
\hline
\end{tabular}


Table.4 Pooled analysis of grain yield of green gram and cost benefit ratio

\begin{tabular}{|c|c|c|c|c|c|c|}
\hline $\begin{array}{l}\text { Trt. } \\
\text { No. }\end{array}$ & Treatments & $\begin{array}{c}\text { Grain } \\
\text { yield } \\
\text { /ha }\end{array}$ & $\begin{array}{c}\text { Gross } \\
\text { income } \\
\text { (Rs./ha) }\end{array}$ & $\begin{array}{l}\text { Cost of } \\
\text { cultivation } \\
\text { (Rs./ha) }\end{array}$ & $\begin{array}{l}\text { Net } \\
\text { income } \\
\text { (Rs./ha) }\end{array}$ & $\begin{array}{l}\text { B:C } \\
\text { ratio }\end{array}$ \\
\hline T1 & STCR recommended dose & 730 & 45,990 & 13,440 & 32,550 & 3.42 \\
\hline T2 & $\mathrm{T} 1+$ Rhizobium $(\mathrm{ST}-600 \mathrm{~g} / \mathrm{ha})$ & 878 & 55,314 & 13,464 & 41,850 & 4.11 \\
\hline T3 & $\begin{array}{l}\mathrm{T} 1+\text { Phosphobacteria (SA- } \\
2 \mathrm{Kg} / \mathrm{ha} \text { ) }\end{array}$ & 818 & 51,534 & 13,520 & 38,014 & 3.81 \\
\hline T4 & $\mathrm{T} 1+\mathrm{AM}$ fungi $\left(\mathrm{SA}-50 \mathrm{~g} / \mathrm{m}^{2}\right)$ & 824 & 53,560 & 19,440 & 34,120 & 2.76 \\
\hline T5 & $\begin{array}{l}\text { T1+ Rhizobium }+ \\
\text { Phosphobacteria }\end{array}$ & 893 & 56,259 & 13,544 & 42,715 & 4.15 \\
\hline T6 & $\mathrm{T} 1+$ Rhizobium + AM fungi & 888 & 55,944 & 19,464 & 36,480 & 2.87 \\
\hline $\mathrm{T7}$ & $\begin{array}{l}\mathrm{T} 1+\text { Phosphobacteria + AM } \\
\text { fungi }\end{array}$ & 847 & 53,361 & 19,520 & 33,841 & 2.73 \\
\hline T8 & $\begin{array}{l}\mathrm{T} 1+\text { Rhizobium }+ \\
\text { Phosphobacteria + AM fungi }\end{array}$ & 1040 & 65,520 & 19,544 & 45,976 & 3.35 \\
\hline & $\mathrm{CD}(0.05 \%)$ & 90 & NA & NA & NA & NA \\
\hline
\end{tabular}

NA-Not analysed

\section{Treatments Details}

\begin{tabular}{|l|l|}
\hline T1 & STCR recommended dose of fertilizer alone \\
\hline T2 & STCR dose + Rhizobium $($ ST $600 \mathrm{~g} / \mathrm{ha})$ \\
\hline T3 & STCR dose + Phosphobacteria $(\mathrm{SA}-2000 \mathrm{~g} / \mathrm{ha})$ \\
\hline T4 & STCR dose + AM fungi $\left(\mathrm{SA}-50 \mathrm{~g} / \mathrm{m}^{2}\right)$ \\
\hline T5 & STCR dose + Rhizobium $(\mathrm{ST}-600 \mathrm{~g} / \mathrm{ha})+$ Phosphobacteria $(\mathrm{SA}-2000 \mathrm{~g} / \mathrm{ha})$ \\
\hline T6 & STCR dose + Rhizobium $(\mathrm{ST}-600 \mathrm{~g} / \mathrm{ha})+$ AM fungi $\left(\mathrm{SA} 50 \mathrm{~g} / \mathrm{m}^{2}\right)$ \\
\hline T7 & STCR dose + Phosphobacteria $(\mathrm{SA}-2000 \mathrm{~g} / \mathrm{ha})+$ AM fungi $\left(\mathrm{SA}-50 \mathrm{~g} / \mathrm{m}^{2}\right)$ \\
\hline T8 & STCR dose + Rhizobium $(\mathrm{ST}-600 \mathrm{~g} / \mathrm{ha})+$ Phosphobacteria $(\mathrm{SA}-2000 \mathrm{~g} / \mathrm{ha})+$ AM fungi $\left(\mathrm{SA} 50 \mathrm{~g} / \mathrm{m}^{2}\right)$ \\
\hline
\end{tabular}

Variety: Paiyur 1 Design: Randomized Block Design Replication: Three

Note: ST: seed treatment; SA: soil application; STCR dose: $23 \mathrm{~kg} \mathrm{~N}+25 \mathrm{~kg} \mathrm{P}_{2} \mathrm{O}_{5}+12.5 \mathrm{~kg} \mathrm{k}_{2} \mathrm{O}+20 \mathrm{~kg} \mathrm{~S} / \mathrm{ha}$

Rajesh et al., (2013) reported that highest yield parameters, number or pods of plants, number of seeds, weight of seeds and weight of 100 seeds were recorded in the crop grown of green gram (Vigna radiata) under the combined application of biofertilizers (Rhizobium leguminosorum, Bacillus megaterium and Bacillum mucilaginosus) when compared with control as well as other treatments. Microorganisms secrete certain organic substances, such as auxins, gibberellins, cytokinins, ethylene and abscisic acid that function as plant growth regulators and influence physiological process resulting in better growth. The use of efficient phosphate solubilizing microorganisms as seed inoculants or direct use in soil when crops are raised greatly help in phosphate solubilization and mobilization for crop use (Gaur, 1992). These findings are in agreement with other reports on marigold and pepper (Dixit et al., 1994), rice and maize (Rajeswar, 2010) and soybean (Zarrei, 2012). The pooled analysis of Kharif 2012 and 2013 revealed 
that the co inoculation of Rhizobium, Phosphobacteria and VAM along with STCR recommended dose of fertilizers recorded highest yield of $1040 \mathrm{~kg} / \mathrm{ha}$ (42.5 percent) with cost benefit ratio of 3.35 compared with STCR alone. The combination of two biofertilizers, Rhizobium along with Phosphobacteria or VAM recorded the yield of 22 percent compared with STCR alone (Table 4). Even though net income was more in the treatment containing VAM inoculation, the cost benefit ratio was less since $500 \mathrm{~kg} /$ ha was used (Rs.30/kg). The VAM inoculum will be reduced subsequent cropping period and recently $5 \mathrm{~g} / \mathrm{m}^{2}$ was standardized by Department of Agriculture Microbiology, TNAU, Coimbatore. Moreover the farmers will get benefit from department by subsidy rate.

\section{References}

Anandaraj. B and Leema Rose Delapierre. 2010. Studies on influence of bioinoculants (Pseudomonas

fluorescens, Rhizobium sp., Bacillus megaterium) in green gram. $\mathrm{J}$ biosci tech, vol 1 (2):95-99

Dixit, S. P. 1994. Effect of paddy straw management of soil fertility build up and yield of cowpea in Wheat paddy cropping system in north-west Himalayan soil. In: proceedings of symposium on Sustainability of rice wheat system in India, karnal, Haryana.
Gaur, C. 1992. Role of phosphorous solubilizing microorganisms in crop productivity and enriched Organic manure. National seminar on organic farming, 28th and 29th sept. 1992, college of Agriculture, Indore, pp. 134142.

Javaid A, Bajwa R, Rabbani N, Uzma M. 2000. EM and VAM Technology in Pakistan. Ix: effect of EM application on growth, yield, nodulation and VA mycorrhizal colonization in Vignaradiata (1) Wilczek. Pak. J. Biol. Sci. 3: 694-698.

Rajesh, M., Kaliyamoorthyjayakumar, M. Satheeskannan. 2013. Effect of biofertilizers application on growth and yield parameters of green gram (Vigna radiata). International journal of environment and bioenergy, 2013, 7(1): 43-53.

Rajeshwar, M., and Ariff Khan, M. A. 2010. Effect of biofertilizers on crop yield and soil available Nutrients of rice and maize in alfisols of Nagarjunasagar left canal command area of Andhra Pradesh, India. An Asian J. Soil Sci., 5: 200-203.

Zarrei, I., Sohrabi, Y., Heidari, G. R., Jalilian, A., and Mohammadi, K. 2012. Effect of biofertilizers on grain yield and protein content of two soybean (Glycine max L.) Cultivars. Afric. J. Biotech., 11: 7028-7037.

\section{How to cite this article:}

Ramalakshmi, A. and Parimala Devi, R. 2018. Performance Evaluation of Co-Inoculation of Rhizobium, Phosphobacteria and AM Fungi in Greengram var Paiyur1. Int.J.Curr.Microbiol.App.Sci. 7(05): 3726-3730. doi: https://doi.org/10.20546/ijcmas.2018.705.431 